УДК 582.711.712(1-924.7)

\title{
Six new species of Alchemilla series Calycinae (Buser) Rothm. (Rosaceae) from the Caucasus
}

\author{
A. V. Chkalov \\ Department of Botany and Zoology, Institute of Biology and Biomedicine, Lobachevsky University, Gagarina Pr. 23, Nizhny \\ Novgorod, 603950,Russian Federation.E-mail: biofor@yandex.ru; ORCID iD: https://orcid.org/0000-0002-3852-7663
}

Keywords: aggregate, apomicts, Georgia, morphology, Russia, taxonomy.

Summary. Descriptions and illustrations of the key morphological characters for six new species of Alchemilla ser. Calycinae (A. bezengiensis, A. kazbekensis, A. longipedicellata, A. muldaschevii, A. pseudotranscancasica, A. ptyschensis) are presented. A. bezengiensis (A. aggr. ellenbergiana) differs from related species by hairy stems throughout and/or densely hairy hypanthia, and/or hairy lower leaf surface. A. kazbekensis ( $A$. aggr. dura) is formally close to A. ser. Elatae by having patent indumentum of stems and petioles that differs it from all other Calycinae. A. longipedicellata (A. aggr. abchasica) is distinguished from most members of the aggregate by fewer leaf lobes and/or glabrous hypanthia, from other Calycinae - by numerous teeth of leaf blades and/or slightly dissected leaves. The three last species belong to $A$. aggr. transcaucasica being quite similar by appearance. A. muldaschevii differs from relatives by having entirely glabrous stems and orbicular upper radical leaves with overlapped basal lobes. A. pseudotranscaucasica, in comparison with others, has evenly hairy leaves beneath and stems hairy throughout, but glabrous hypanthia. A. ptyschensis is distinguished from other species of the aggregate by stems hairy only at the lowermost internode; from other Calycinae - besides the stem indumentum by longer truncate leaf lobes and glabrous at the base main veins of leaf blades.

\section{Шесть новых видов ряда Calycinae (Buser) Rothm. (Alchemilla, Rosaceae) из Кавказа}

\author{
А. В. Чкалов \\ Национальный исследовательский Нижегородский государственный университет им. Н. И. Лобачевского, \\ пр. Гагарина, д. 23, г. Нижний Новгород, 603950, Россия
}

Ключевые слова: агрегат, апомикты, Грузия, морфология, Россия, таксономия.

Аннотация. Alchemilla ряда Calycinae (A. bezengiensis, A. kazbekensis, A. longipedicellata, A. muldaschevii, A. pseudotranscaucasica, A. ptyschensis). A. bezengiensis (A. aggr. ellenbergiana) отличается от родственных видов полностью опушенными стеблями и/или густо опушенными гипантиями, и/или опушенной нижней поверхностью листьев. A. kazbekensis (A. aggr. dura) формально близок A. ser. Elatae благодаря оттопыренному опушению стеблей и черешков, которое отличает его от всех других представителей ряда Calycinae. A. longipedicellata (A. aggr. abchasica) выделяется среди других представителей агрегата меньшим количеством лопастей листьев и/или голыми гипантиями. Последние три вида принадлежат к $A$. aggr. transcaucasica, будучи при этом довольно схожими внешне. A. muldaschevii обладает, в сравнении с близкими видами, совершенно голыми стеблями и округлыми верхними прикорневыми листьями с перекрывающимися краевыми лопастями. A. pseudotranscaucasica отличается от других представителей равномерно опушенными листьями снизу, полностью опушенными стеблями, но при этом голыми гипантиями. A. ptyschensis же, в отличие от других видов агрегата, имеет стебли, опушенные только на самом нижнем междоузлии; от многих других видов Calycinae отличается, помимо опушения стеблей, относительно большей длиной притупленных лопастей и голыми при основании главными жилками листьев. 


\section{Introduction}

While preparing a "Caucasian Flora Conspectus" (2008), numerous collections in the Herbarium of the V. L. Komarov Botanical Institute of Russian Academy of Sciences (Saint-Petersburg, Russia) (LE) were researched. Analysing previous studies of Alchemilla L. species diversity in the Caucasus region (Buser, 1894, 1896, 1906a, b; Rothmaler, 1933; Juzepczuk, 1934a, b; Rothmaler, 1938, 1939; Juzepczuk, 1941, 1957, 1967), Crimea (Juzepczuk, 1933, 1938), Iran (Fröhner, 1969), and Turkey (Pawłowski, 1972; Pawłowski, Walters, 1972; Ponert, 1973; Kalheber, 1994; HayirlioğluAyaz, Beyazoğlu, 1997; Hayirlioğlu-Ayaz, 2000; Hayirlioğlu-Ayaz, Kalheber, 2002), I came to conclusion that some specimens should be considered as representatives of several new species, and six of them belong to $A$. ser. Calycinae (Buser) Rothm. Review for a new system of aggregates within this series was presented earlier (Chkalov, 2020). There, a key for all Caucasian members of the series, including species described below, was introduced. The aim of this study is to describe new for science Alchemilla species.

\section{Materials and methods}

The study is based on a morphological approach. The material of Caucasian Alchemilla in LE and MW was investigated by the author. Many samples of the original material for comparison were obtained through on-line platforms: B (Curators Herbarium B. URL: http://ww2.bgbm.org); C, M (JSTOR. URL: https://plants.jstor.org); E (RBGE. URL: https://data.rbge.org.uk); FI (Museo di Storia Naturale - Sezione Botanica "F. Parlatore" dell'Università di Firenze. URL: http://parlatore. msn.unifi.it); $\mathrm{G}$ (Catalogue des herbiers de Genève (CHG). URL: http://www.ville-ge.ch); H (FinBIF. URL: https://aji.fi/); K (Kew. URL: http://apps. kew.org); MW (Seregin. URL: https://plant.depo. msu.ru); P (MNHN. URL: https://science.mnhn.fr); S (Herbarium Catalogue (S). URL: http://herbarium.nrm.se); W, WU, JE (Virtual Herbaria. URL: https://herbarium.univie.ac.at). Terminology used in the descriptions was explained elsewhere (Chkalov, 2011, 2015). Distribution of species is characterised according to a scheme applied in the "Caucasian Flora Conspectus" (2008) and presented below taking into account also the specimens non-cited here.

\section{Six new species of Alchemilla}

Alchemilla bezengiensis Czkalov, sp. nov. (Figs. 1, 2; table)

(A. ser. Calycinae (Buser) Rothm., A. aggr. ellenbergiana Rothm.).

Type: "[Russia] Terskaya oblast, alpine [...] (WNW) adjacent to the Ullu-Guluk plateau, upper reaches of the Bezengi river. 10 VII 1913. E. A. and N. A. Busch" (LE-01072764!).

Description. Plant of small size, $10-30 \mathrm{~cm}$. Rhizome, rather thin, up to $0.8 \mathrm{~cm}$. Stems $3-4$, ascendent, 2-4 times higher than radical leaves, up to 30 $\mathrm{cm}$, evenly densely or sparsely pubescent throughout with appressed silky hairs.

All radical leaves similar, up to $9 \mathrm{~cm}$, leaf blade length $1.5-2.5 \mathrm{~cm}$, widely reniform or reniform, undulate, angle of sector $32-42^{\circ}$, hairy only on the teeth and folds above, evenly \pm densely hairy beneath; 5-7-lobed, lobes 19-25\%, central zone 67-74\%, first principal vein $96-103 \%$, second principal vein $87-96 \%$ of leaf length (1. 1.); with lobes arcuate to semicircular, with incisions between lobes $12-17 \%$ of 1. 1., 19-25\% of lobe length, with distance between bases of incisions 107-121\% of lobe width, with width $211-300 \%$ of lobe length; with 4-5 teeth at each side of lobe, acutish, equally-sided, triangularly ovate, straight, slightly curved, almost equally sized, the lowermost teeth to 1.5 times less than the standard tooth; length of standard tooth $8-10 \%$ of 1. 1., $40-46 \%$ of lobe length, with apical tooth 50 $69 \%$ of standard tooth length, a bit shorter than neighboring ones. Leaves with $60-100$ teeth in total. Petioles densely pubescent throughout with appressed silky hairs. Stipules of radical leaves brownish.

Stem leaves 2-3 per stem, evenly spread along it, beside the lowermost inflorescence branch widely obovate, cuneate, sessile, central zone $59-74 \%$ of 1. 1., 1-lobed, with two basal lobes, lobes $9-11 \%$ of 1. 1., with 1-2 teeth at each side, plain, 13-20 teeth in total. Inflorescence narrow and poor, with 1-2(3) inflorescence branches, assembled in the upper $1 / 3-$ $1 / 2$ of stem. The lowermost inflorescence branch 1-2 times longer than internode, with hairy branchlets throughout, each with 2-3 nodes, 10-20 flowers. Monochasia dense, the lateral with almost no stipule (0-0.5 of pedicel length), with no axis, 4-5 flowers. Terminal monochasia similar to lateral ones. Flowers of medium size, hypanthia shortly obconical, with fruit campanulate or semiglobose, without 
neck, entirely hairy with appressed hairs, $0.90-1.65$ $\mathrm{mm}$ lg., ratio width : length (w/1 ratio) $67-100 \%$; pedicels 1.5-3(4) hypanthia $1 \mathrm{~g}$., glabrous. Sepals triangular ovate, (0.90)1.25-1.60 mm lg., (76)85$140 \%$ of hypanthium $1 \mathrm{~g}$., w/1 ratio $44-72(111) \%$, ciliate or barbulate. Epicalyx segments lanceolate to ovate, (0.65)1.20-1.35 mm lg., 65-125(144) \% of hypanthium lg., 72-104\% of sepal lg., width $40-61(82) \%$ of sepal width, w/1 ratio 31-44(62) \%, glabrous or rarely ciliate.

Distribution and habitat. Alpine belt in the Central Caucasus, Eastern Transcaucasus.

4. CC: 4b. Malk.; 9. ETC: 9d. Murgh.-Murovd.

Affinity. A. retinerviformis Juz. differs from this species by orbicular and orbicular reniform leaves and glabrous lower leaf surfaces; A. akdoganica Kalheber differs by having glabrous upper internodes of stem, less numerous leaf lobes, and more teeth on them (6-7 at each side); A. ancerensis Kalheber, in comparison with this species, has glabrous upper internodes of stem, subglabrous leaf blades beneath, barely hairy hypanthia; $A$. stricta Rothm. is distinguished by glabrous upper internodes of stem, glabrous lower leaf surfaces, and greater number of teeth of leaf lobes (7-9 at each side); A. wischniewski Rothm. and A. ellenbergiana Rothm. (A. beyazoglii Kalheber) differ by having glabrous hypanthia; $A$. venosa Juz. differs by orbicular or orbicular reniform leaves, barely hairy hypanthia, and larger angle of leaf sector $\left(40-50^{\circ}\right)$.

Etymology. The species is named after the river ("Bezengi") in the basin of which it was collected.

\section{$1,3)$}

Alchemilla kazbekensis Czkalov, sp. nov. (Figs.

(A. ser. Calycinae (Buser) Rothm., A. aggr. dura Buser).

Type: "[Georgia] Tiflis province, Dusheti distr., Mt. Kazbek, near the Dezdorak glacier, gravelly slope beside snowfield. 3 VIII 1916, P. N. Krylov, E. I. Steinberg" (LE-01072770!).

Paratype: "[Russia] N. A. Busch, Iter caucasicum VIII. Kuban prov., 1907, N. Busch, B. Klopotow 721" (LE-01072771!).

Description. Plant of medium size, up to $18-21$ $\mathrm{cm}$. Rhizome rather thick, up to $1 \mathrm{~cm}$. Stem $1-5$, erect, ascendant or prostrate, 2-3 times higher than radical leaves, up to $21 \mathrm{~cm}$, densely pubescent with erectopatent hairs on the lower half, sparsely in the upper half, to glabrous in the 1-2 uppermost internodes.
All radical leaves similar, up to $4-10 \mathrm{~cm}$, leaf blade length $2.5-3.5 \mathrm{~cm}$, orbicular reniform to orbicular with overlapped basal lobes (in the smallest plants), \pm undulate, angle of sector $35-41^{\circ}$, glabrous, hairy only on the teeth, to sparsely pubescent above, evenly densely hairy beneath; 7-9-lobed, lobes $23-29 \%$, central zone $67-75 \%$, first principal vein $97-100 \%$, second principal vein $83-91 \%$ of 1.1.; with lobes arcuate to semicircular, with incisions between lobes $6-12.5 \%$ of 1. 1., 23-29\% of lobe length, with distance between bases of incisions $108-123 \%$ of lobe width, width $170-244 \%$ of lobe length; with 5-7(8) teeth at each side of lobe, acute, equally-sided, triangular, triangular falcate, straight, curved, almost equally-sized, the lowermost teeth to 1.5 times less than the standard tooth; length of standard tooth $6.5-9.5 \%$ of $1.1 ., 26-42 \%$ of lobe length, with apical tooth $67-100 \%$ of standard tooth length, similar size to neighboring ones. Leaves with 90-125 teeth, petioles densely pubescent throughout with erectopatent hairs, with stipules brown or purplish.

Evenly-spread stem leaves numbering (4)5-6 per stem beside the lowermost inflorescence branch reniform or widely reniform, truncate or subcordate, almost sessile, petioles less than 1/4 of leaf length; the lower leaves with long petioles, central zone $63-$ $66 \%$ of 1. 1., 4-5-lobed (without the two basal ones); lobes $28-31 \%$ of 1.1 ., with $4-5$ teeth at each side, \pm undulate, $50-65$ teeth in total. Inflorescence narrow and very poor, with 2-3(4) inflorescence branches, assembled in the upper $1 / 5-1 / 4$ of stem. The lowermost inflorescence branch 0.5-1.3 times longer than its internode, with glabrous branchlets (except the lowermost branchlets), with 3-5 nodes, 5-20 flowers. Monochasia quite dense, the lateral with almost no stipule, $0-0.5$ of pedicel length, with no axis, 4-5 flowers. Terminal monochasia with almost distinct stipule, 1-2 of pedicel length, with axis about 1 of pedicel length, 4-5 flowers. Flowers of large size, hypanthia shortly obconical, with fruit shortly campanulate or semiglobose, with neck, glabrous, $1.15-1.50 \mathrm{~mm} \mathrm{lg}$., w/1 ratio $46-60 \%$; pedicels $1.5-$ 3(5) hypanthia lg., glabrous. Sepals narrowly ovate to ovate, $1.38-2.00 \mathrm{~mm} \lg$., $120-150(163) \%$ of hypanthium lg., w/l ratio 35-58 \%, glabrous. Epicalyx segments lanceolate to narrowly ovate, (1.43)1.70$2.50 \mathrm{~mm} \lg$., 114-150(208) \% of hypanthium lg., $76-128 \%$ of sepal lg., width $68-81(117) \%$ of sepal width, w/1 ratio $26-45 \%$, glabrous. 


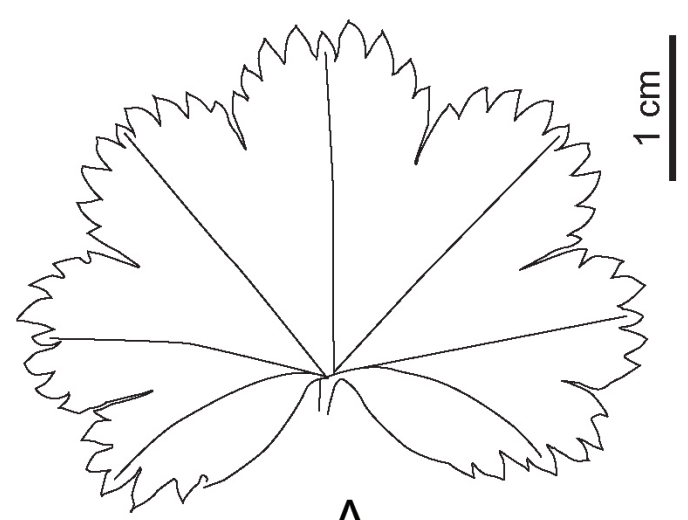

A

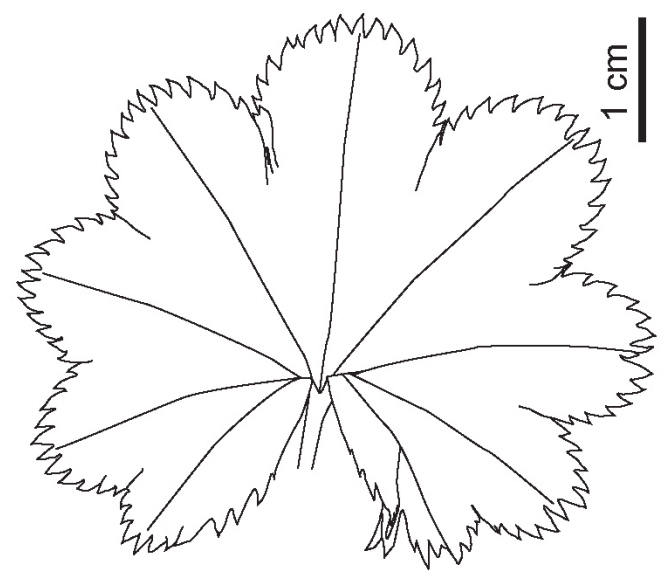

$\mathrm{F}$

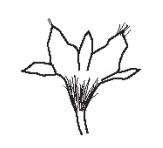

B

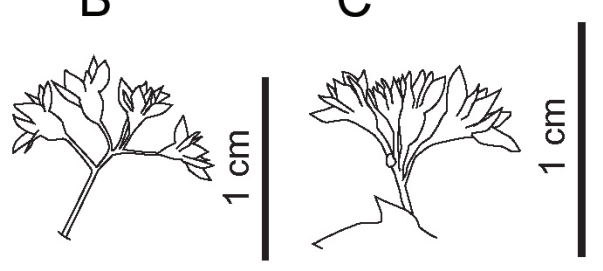

D
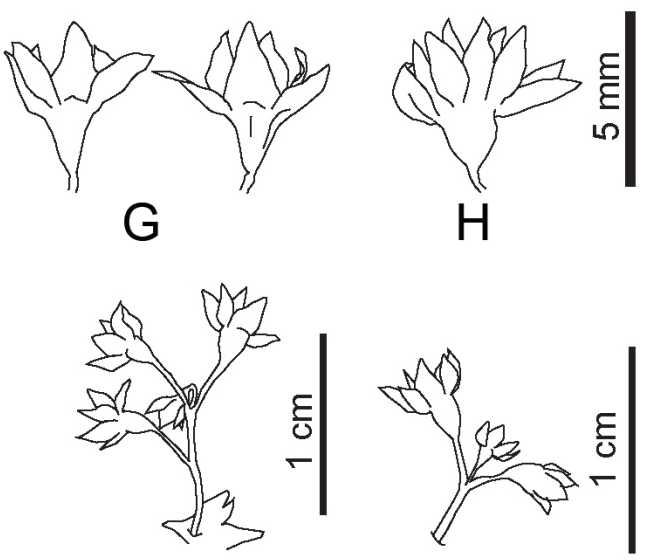

I

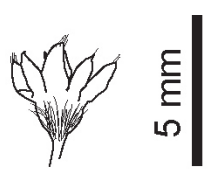

C

$E$

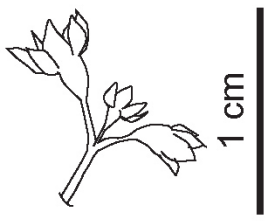

$\mathrm{J}$

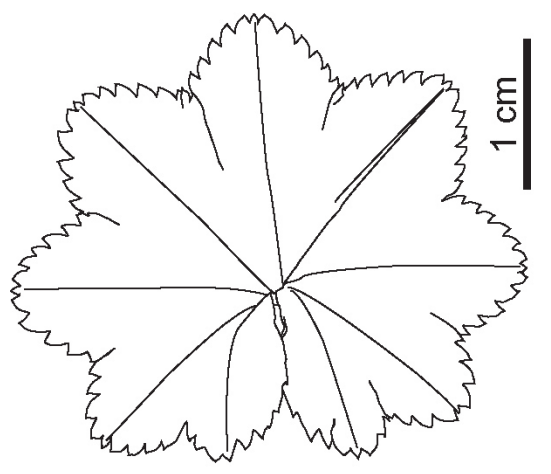

$\mathrm{K}$

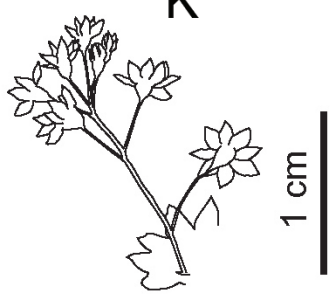

$\mathrm{M}$

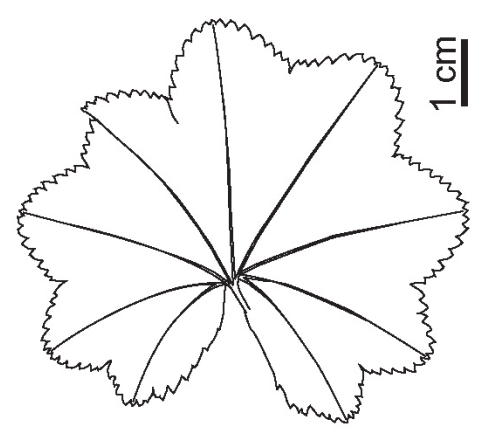

$\mathrm{L}$

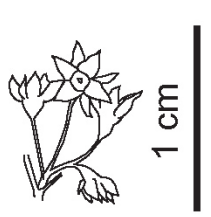

$\mathrm{N}$

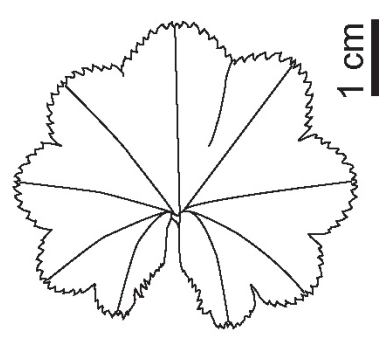

M

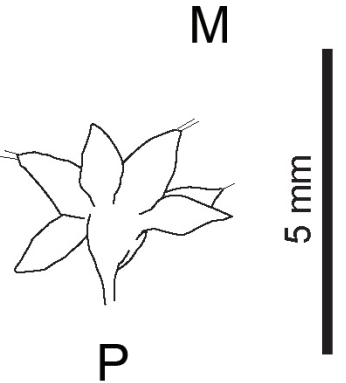

Fig. 1. Morphological features of Alchemilla species. A. bezengiensis: A - leaf blade of radical leaf; B - blooming flower; $\mathrm{C}$ - flower with mature fruit; D - terminal monochasium; E - lateral monochasium. A. kazbekensis: $\mathrm{F}$ - leaf blade of radical leaf; $\mathrm{G}$ - blooming flower; $\mathrm{H}$ - flower with mature fruit; I - terminal monochasium; $\mathrm{J}$ - lateral monochasium. A. longipedicellata: $\mathrm{K}$ - leaf blade of upper radical leaf; $\mathrm{L}$ - leaf blade of medium radical leaf; $\mathrm{M}$ - leaf blade of lower radical leaf; $\mathrm{N}$ - terminal monochasium; $\mathrm{O}$ - lateral monochasium; $\mathrm{P}$ - blooming flower; $\mathrm{Q}$ - flower with mature fruit. 


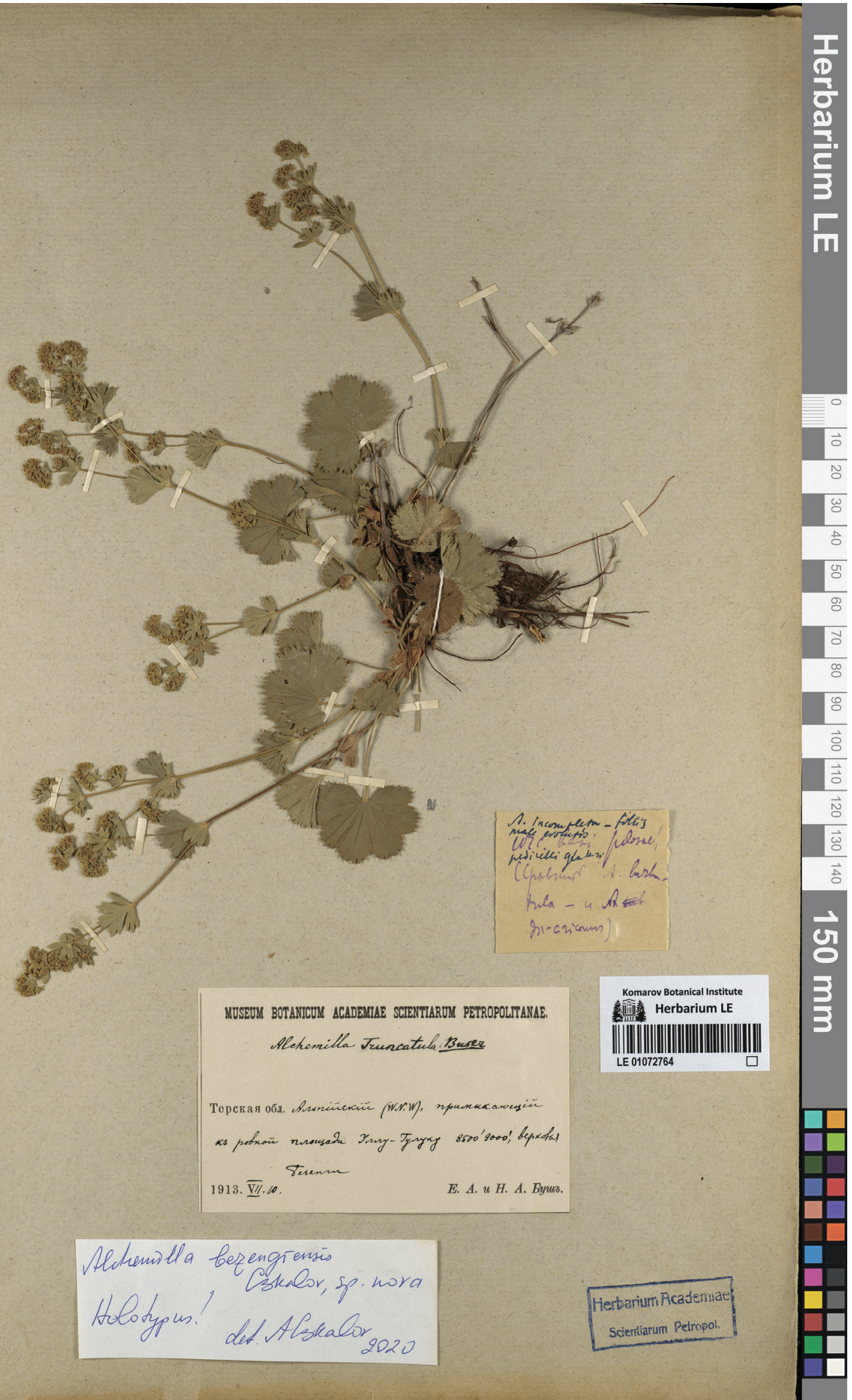

Fig. 2. Holotype specimen of Alchemilla bezengiensis. 
Distribution and habitat. Grows in alpine belt in the Western Ciscaucasus and Central Transcaucasus.

3. WC: ?; 8. CTC: 8a. Kart.-S. Oss.

Affinity. From all the "true" Calycinae species, it is distinguished by patent indumentum. The species of $A$. ser. Elatae, which are related by the formal features, such as $A$. epipsila Juz., A. stellulata Juz., A. circassica Juz., A. laeta Juz., A. hessii Rothm., differ from this species by having numerous teeth on leaf lobes, (7)8-10 at each their side, short incisions between lobes (less than standard tooth length), and overall appearance.

Etymology. The species is named after the mountain ("Kazbek"), where it was collected.

Alchemilla longipedicellata Czkalov, sp. nov. (Figs. 1, 4)

(A. ser. Calycinae (Buser) Rothm., A. aggr. $a b-$ chasica Buser).

Type: "[Russia] Circassia, prope opp. Krasnaja Poljana, m. Atshishcho, prope stat. meteorologicam, in declivibus lapidosis. 24 VII 1937. S. Juzepczuk 250" (LE-01072774!, specimen marked by asterisk).

Paratype: "[Russia] Circassia, prope opp. Krasnaja Poljana, m. Atshishcho, inter stat. meteorologicam et cataractam, in declivibus umbrosis in fagetoaltiherbeto, ad tramitem, 1937, S. Juzepczuk 373" (LE-01072775!).

Description. Plant of varying size, small to large, $12-45 \mathrm{~cm}$. Rhizome rather thin, up to $0.8 \mathrm{~cm}$. Stems 2-4, ascendent or erect, rather slender, 1.53(4) times higher than radical leaves, up to $45 \mathrm{~cm}$, glabrous, except for the lowermost internode with appressed indumentum.

Lower and medium radical leaves orbicular reniform or reniform with narrow sinus or touching basal lobes, with angle of sector $37-39^{\circ}$, mostly glabrous, hairy only along main veins and on basal lobes beneath; 5-7-lobed, with lobes 17-28\%, central zone $70-84 \%$ of 1 . 1 . Lobes arcuate, somewhat triangular in shape, or plain, with incisions among lobes $6-14.5 \%$ of $1.1 ., 23-52 \%$ of lobe length, with 5-6 teeth at both sides of lobe, acutish, almost equally-sided, widely triangular mammillate, straight, curved, equally sized; length of standard tooth $4-7.5 \%$ of 1.1 ., 16-27 \% of lobe length, with apical tooth $32-50 \%$ of standard tooth length, much smaller than the neighboring ones. Leaves with 65105 teeth in total. Petioles densely pubescent with appressed hairs.

Upper radical leaves 3-30 cm, leaf blade length $1.5-5.5 \mathrm{~cm}$, orbicular with overlapped basal lobes, rather undulate and plicate, angle of sector to $45^{\circ}$, glabrous above, sparsely hairy beneath, densely on basal lobes, with glabrous $1 / 4-1 / 2$ of main veins; $7-9$-lobed, lobes to $30 \%$, central zone from $68 \%$ of 1.1.; with lobes arcuate to widely semiovate, somewhat triangular in shape; with incisions between lobes from $3.5 \%$ of 1 . 1., from $12 \%$ of lobe length, with distance between bases of incisions 108-111\% of lobe width, width 197-218\% of lobe length; with 6-8(9) teeth at each side of lobe, acutish or almost obtuse, unequally-sided, semiovate or triangularly semiovate, outwardly oblique, curved, unequally sized teeth, teeth of middle of the lobe up to 3 times larger than the lowermost one; length of standard tooth from $5 \%$ of 1.1 ., from $16 \%$ of lobe length, with apical tooth from $32 \%$ of standard tooth length, much smaller then neighboring ones, but at the same level. Leaves with 100-150 teeth in total. Petioles pubescent with appressed hairs. Stipules of radical leaves purple.

Evenly-spread stem leaves numbering 5-7 per stem, beside the lowermost inflorescence branch orbicular reniform, with short petioles $1 / 5-1 / 4$, central zone $67-74 \%$ of $1.1 ., 5$-lobed, lobes $19-23 \%$ of 1.1 ., with 4-5 teeth at each side, arcuate to shortly parabolic, with 46-64 teeth in total. Inflorescence rather wide, with 2-4 widespread inflorescence branches, assembled in the upper $1 / 3-1 / 2$ of stem. The lowermost inflorescence branch (0.5)1-2.5 times longer than its internode, with glabrous branchlets, 2-6 nodes, (5)10-35 flowers. Monochasia quite lax, the lateral with stipule, $0.5-1$ of pedicel length, with distinct axis (0.5-1 of pedicel length), 3-5 flowers. Terminal monochasia with distinct stipule 0.5-2 pedicel length, distinct axis (1-2 of pedicel length), 6-9 flowers. Flowers of small size, hypanthia very shortly obconical, with fruit shortly campanulate or obconical, without neck, glabrous, (0.75)0.90-1.45 $\mathrm{mm}$ lg., w/1 ratio 73-93(110) \%; pedicels very long, 3-6(8) hypanthia $\lg$., glabrous. Sepals ovate to widely triangular ovate, $1.00-1.45 \mathrm{~mm} \lg ., 100-133 \%$ of hypanthium $1 g$., w/1 ratio $51-80 \%$, ciliate. Epicalyx segments narrowly triangular ovate to lanceolate, $1.08-1.73 \mathrm{~mm} \mathrm{lg.,} \mathrm{107-120(150)} \mathrm{\%} \mathrm{of} \mathrm{hypanthium}$ lg., 104-119\% of sepal lg., width 56-104\% of sepal width, w/1 ratio $41-51 \%$, glabrous.

Distribution and habitat. Grows in herbaceous places in mountain forests and on slopes in the Western Transcaucasus.

7. WTC: 7a. Tuap.-Adl.

Affinity. From most species of $A$. ser. Calycinae (such as $A$. retinervis Buser) with glabrous hypanthia, it differs by having barely dissected leaves. 
A. procerrima S. E. Fröhner differs by higher pubescent stems, up to $2 / 3$ of their height, hairy main veins throughout; $A$. debilis Juz., being similar in appearance, is distinguished by glabrous bases of main veins of lower leaves and hairy those of upper leaves, by widely reniform lower leaves with very wide sinus (angle between veins of basal lobes more than $110^{\circ}$ ), fewer teeth number of stem leaves (2-3 at each lobe side); $A$. dura Buser differs by having very falcate curved teeth of leaves, obtuse leaf lobes (vs. a kind of triangular or rounded ones), bigger angle of leaf sector $\left(40-50^{\circ}\right)$ of the lower and medium leaves. It differs from most species of $A$. aggr. abchasica through glabrous hypanthia and fewer leaf lobes.

Etymology. The species is named due to its very specific elongate pedicels.

Alchemilla muldaschevii Czkalov, sp. nov. (Figs. 5, 6)

(A. ser. Calycinae (Buser) Rothm., A. aggr. transcaucasica).

Type: "[Georgia] Abchasia, trajectus Kluchor, in initio viae (vetustae) Militari-Suchumensis juxta ejus marginem. 25 VIII 1937. S. Juzepczuk 856" (LE-01072779!, specimen marked by asterisk).

Paratypes: "[Russia] Reg. auton. Karatshai, prope pag. Dombai, in faucib. fl. Ptysh ad cataractam I, in schistosis. 1937. S. Juzepczuk 939" (LE-01072781!, + duplicate 935, LE-01072783!, LE-01072810!); “prope pag. Teberda, in faucib. fl. Azgek, loco herboso ad ripam fluvii, 1937, S. Juzepczuk 538" (LE-01072780!, LE-01072782!).

Description. Plant of small or medium size, 10 $30 \mathrm{~cm}$. Rhizome rather thin, up to $0.8 \mathrm{~cm}$. Stems 1-3, ascendent, rather robust, 1.5-3 times higher than radical leaves, up to $30 \mathrm{~cm}$, glabrous in all internodes.

Lower and medium radical leaves orbicular or reniform with very narrow sinus, with angle of sector (37) $42-47^{\circ}$, glabrous in most, hairy only along the upper $1 / 3-1 / 2$ of main veins; 5-7-lobed, with lobes $22.5-24 \%$, central zone $70-77 \%$ of 1 . 1. Lobes plain or arcuate, often obtuse, with incisions among lobes $8-14 \%$ of $1.1 ., 34-63 \%$ of lobe length, with 4-5 teeth at both sides of lobe, acutish, almost equallysided, widely triangular mammillate, outwardly directed, curved, equally sized; length of standard tooth $6.5-10.0 \%$ of $1.1 ., 27-43 \%$ of lobe length, with apical tooth $43-74 \%$ of standard tooth length, much smaller than neighboring ones, thus, lobes at the tops recessed. Leaves with 60-100 teeth in total. Petioles glabrous.
Upper radical leaves up to $15 \mathrm{~cm}$, leaf blade length $1.5-3.5 \mathrm{~cm}$, orbicular with overlapped basal lobes, rather undulate and plicate, angle of sector to $51^{\circ}$, glabrous, except for the upper $1 / 3-1 / 2$ of main veins, but leaves with hairy petioles pubescent on the veins throughout; 7-9-lobed, lobes to $36 \%$, central zone from $59 \%$ of 1.1 .; with lobes arcuate to triangularly semicircular and equally-sided triangular, with incisions between lobes from $7 \%$ of 1.1 , to $36 \%$ of lobe length, with distance between bases of incisions $100-140 \%$ of lobe width, with width $130-200 \%$ of lobe length; with 6-7 teeth at each side of lobe, acute, very unequally-sided, triangularly ovate, straight, oblique, curved, unequally sized, lowermost teeth up to 3 times shorter than standard tooth; length of standard tooth to $11(13) \%$ of 1.1 , from $27 \%$ of lobe length, with apical tooth from $33 \%$ of standard tooth length. Leaves with 100 $120(135)$ teeth in total. Petioles mostly glabrous, some evenly pubescent with appressed hairs. Stipules of radical leaves purple.

Evenly-spread stem leaves 5-7 per stem, beside the lowermost inflorescence branch reniform or widely reniform, with short petioles $1 / 5-1 / 4$, central zone $67-80(87) \%$ of 1. 1., 5-lobed, lobes (20)23$26 \%$ of 1 . 1., with $4-5$ teeth at each side, plain to shortly parabolic, with $36-75$ teeth in total. Inflorescence rather wide, with 3-4(5) widespread inflorescence branches, assembled in the upper third, rarely in the upper half of stem. The lowermost inflorescence branch 0.5-2 times longer than its internode, with glabrous branchlets, 2-8 nodes, (5)15-40 flowers. Monochasia quite lax, the lateral with stipule 1-2 of pedicel length, clear axis, 1.5-2 of pedicel length, 6-9 flowers. Terminal monochasia with stipule $0.5-1(3)$ pedicel length, clear axis (1-2 of pedicel length), 7-10 flowers. Flowers of medium size, hypanthia shortly obconical, with fruit shortly campanulate or semiglobose, without neck, glabrous or rarely with solitary hairs, $1.10-1.50 \mathrm{~mm}$ lg., w/1 ratio $67-95 \%$; pedicels 1.5-3(4) hypanthia lg., glabrous. Sepals elongate ovate or ovate, $1.12-1.40$ mm lg., (85)113-124 \% of hypanthium $1 \mathrm{~g}$., w/1 ratio $58-82 \%$, glabrous. Epicalyx segments narrowly lanceolate, $1.13-1.43(1.63) \mathrm{mm} \mathrm{lg.,} 102-138 \%$ of hypanthium lg., (87)102-130 \% of sepal lg., width $60-87 \%$ of sepal width, w/l ratio $32-54 \%$, glabrous or rarely with solitary hairs.

Distribution and habitat. Grows in herbaceous places along dirt roads and river banks, in rock crevices in the Western Transcaucasus, Western and Central Ciscaucasus. 


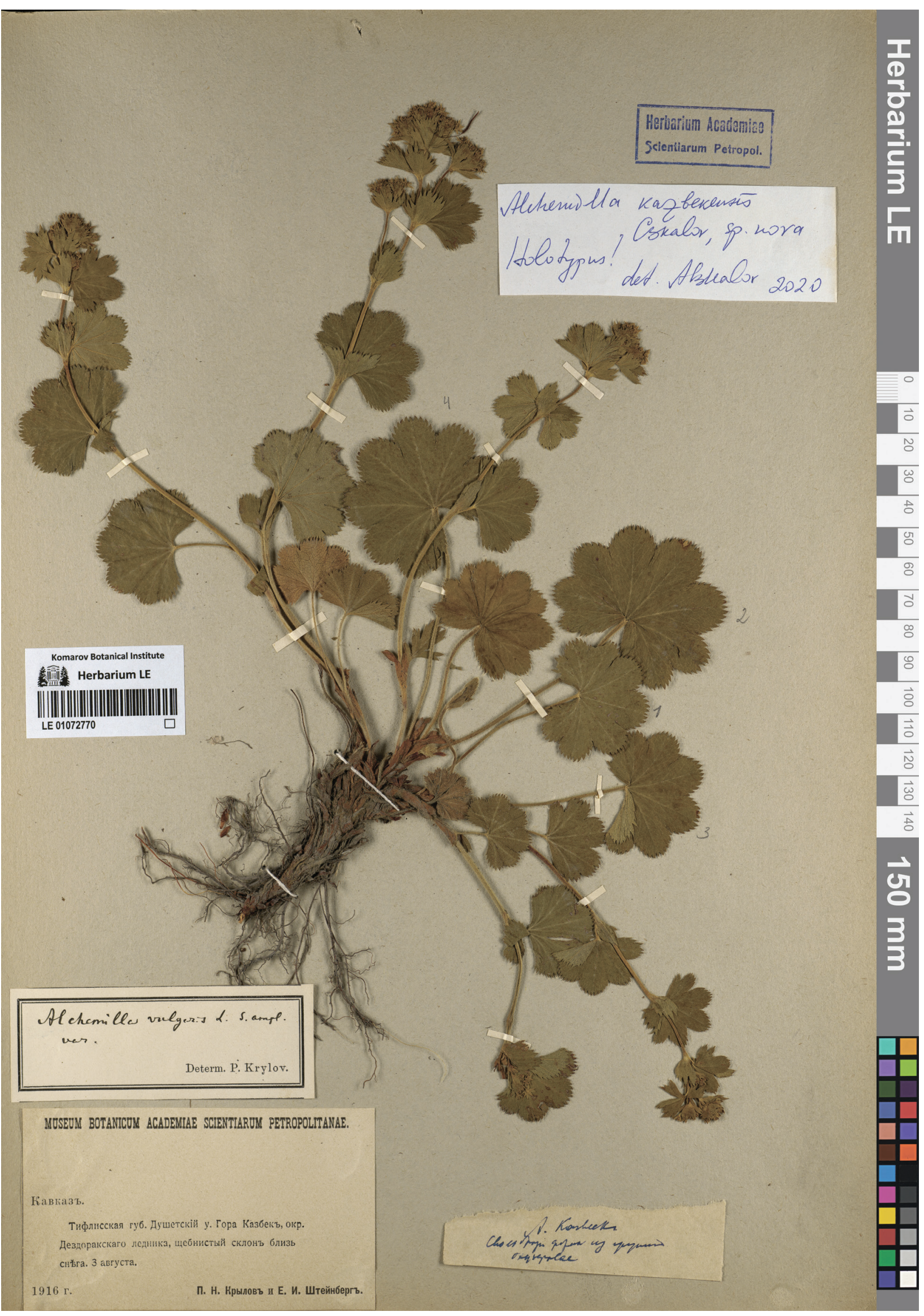

Fig. 3. Holotype of Alchemilla kazbekensis. 


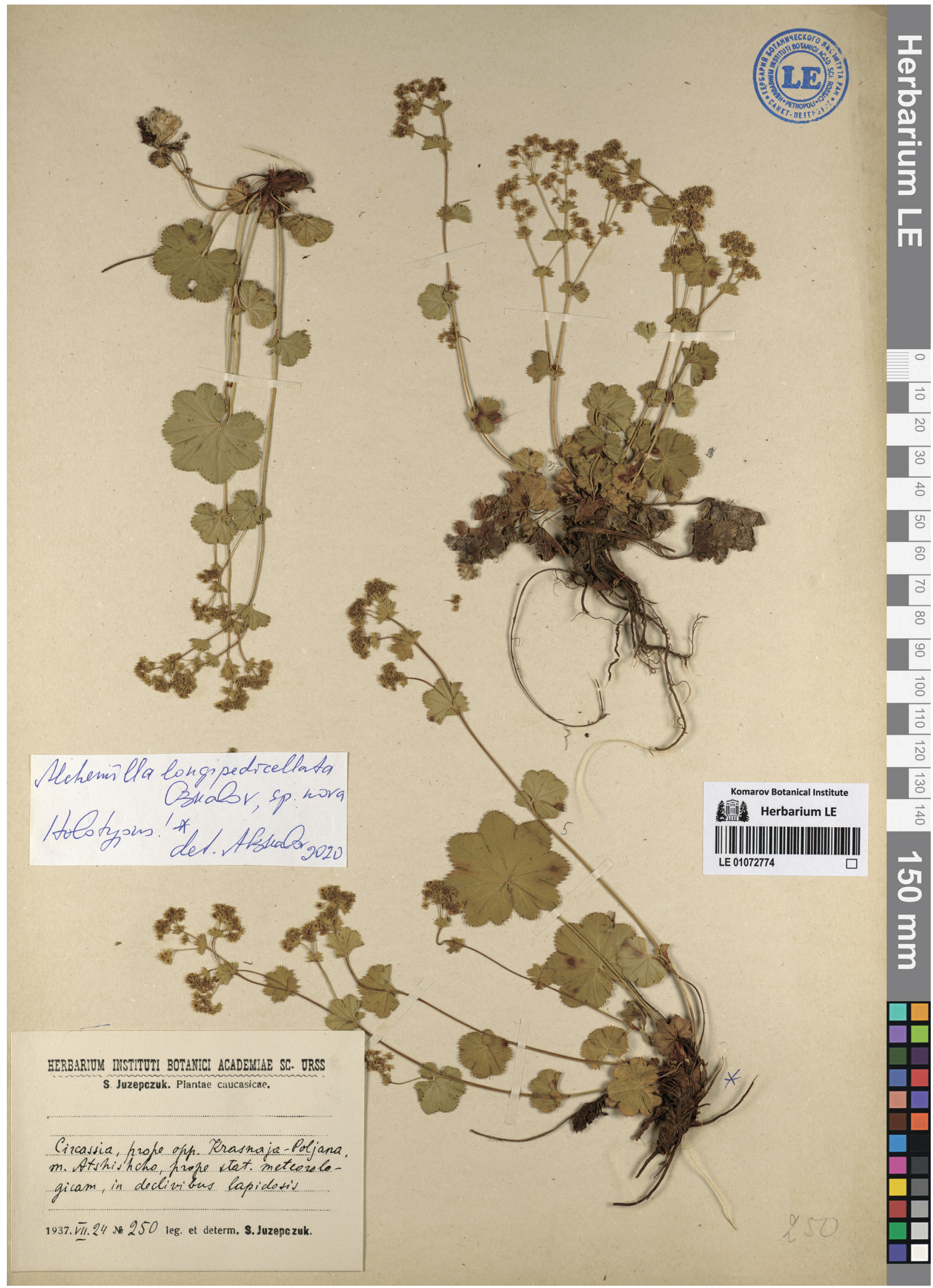

Fig. 4. Holotype specimen of Alchemilla longipedicellata. 
3. WC: 3c. Urup.-Teb.; 7. WTC: 7a. Tuap.-Adl., 7b. Abkh.; 8. CTC: 8a. Kart.-S. Oss.

Affinity. From most species of this series A. muldaschevii differs by entirely glabrous stems and orbicular upper leaves with overlapped basal lobes (including descripted below A. pseudotranscaucasica, A. ptyschensis). The last also differs by hairy petioles of all leaves, narrower sepals, short axis of monochasium, and by having a neck of flowers with fruits. A. adelodictya Juz. differs from this species by having all glabrous petioles of radical leaves (vs. \pm hairy), most leaf blades being widely reniform or reniform with semicircular lobes (vs. mostly orbicular leaf blades with lobes to triangular); A. microdictya Juz. is distinguished by rounded leaf lobes and deeper incisions between them (1.52.5 of standard tooth length) vs. triangular ones with incisions $0.5-1.5$ of standard tooth length.

Etymology. The species was named in honour of Uralian florist and Alchemilla collector Albert A. Muldashev (Ufa Institute of Biology, Ufa Federal Research Center of Russian Academy of Sciences, Ufa, Russia).

Alchemilla pseudotranscaucasica Czkalov, sp. nov. (Figs. 5, 7)

(A. ser. Calycinae (Buser) Rothm., A. aggr. transcaucasica Rothm.).

Type: "[Georgia] Abchasia, trajectus Kluchor, in initio viae (vetustae), Militari-Suchumensis juxta ejus marginem. 25 VIII 1937. S. Juzepczuk" (LE01072790!, specimen marked by asterisk).

Description. Plant of small or medium size, up to $25 \mathrm{~cm}$. Rhizome quite thin, up to $0.7 \mathrm{~cm}$. Stems $1-3$, erect or ascendent, rather robust, 1.5-2 times higher than radical leaves, up to $25 \mathrm{~cm}$, sparsely hairy with appressed hairs throughout.

Lower and medium radical leaves reniform with narrow sinus or touching basal lobes to orbicular with overlapped basal lobes, with angle of sector $53-65^{\circ}$, the lowermost nearly entirely glabrous, hairy only along the upper $1 / 2-3 / 4$ of main veins, but in most hairy on the teeth above and evenly hairy with appressed hairs beneath; 5-7-lobed, with lobes $24-33 \%$, central zone $63-73 \%$ of 1 . 1. Lobes plain or shortly trapezoids, obtuse, with incisions among lobes $5-13 \%$ of 1.1 ., 16-34(54) \% of lobe length, with 5-6 teeth at both sides of lobe, acutish, unequally-sided, triangular mammillate, triangular falcate, outwardly oblique, equally sized; length of standard tooth $8-12.5 \%$ of $1.1 ., 23-36 \%$ of lobe length, with apical tooth $43-53 \%$ of standard tooth length, much smaller than neighboring ones, thus, lobes at the tops recessed. Leaves with 55-95 teeth in total. Petioles sparsely pubescent with appressed or subappressed hairs.

Upper radical leaves up to $11 \mathrm{~cm}$, leaf blade length $2.5-4 \mathrm{~cm}$, orbicular reniform with narrow sinus, slightly undulate, angle of sector from $44^{\circ}$, with the same indumentum as the others; 5-7-lobed, lobes to $35 \%$, central zone from $60 \%$ of 1 . 1.; with lobes trapezoid or semiovate, with incisions between lobes from $7 \%$ of 1.1 , to $35 \%$ of lobe length, with distance between bases of incisions 113-118\% of lobe width, with width about $160 \%$ of lobe length; with 7-9 teeth at each side of lobe, acute, almost unequally-sided, triangular falcate, outwardly oblique, unequally sized, the lowermost teeth to 5 times less than the standard tooth; length of standard tooth to $12.5 \%$ of 1.1 ., to $36 \%$ of lobe length, with apical tooth from $27 \%$ of standard tooth length. Leaves with 85-110 teeth in total. Petioles pubescent with appressed hairs. Stipules of radical leaves purple.

Mostly evenly-spread stem leaves 4-6 per stem, beside the lowermost inflorescence branch reniform or orbicular reniform, subcordate or truncate, with short petioles $0-25 \%$, central zone $67-80(87) \%$ of 1 . 1., 5-lobed, lobes (20)23-26\% of 1. 1., with 3-4 teeth at each side, arcuate to trapezoid, with $29-45$ teeth in total. Inflorescence rather narrow, with (2)3-4 inflorescence branches, assembled in the upper $1 / 4-1 / 2$ of stem. The lowermost inflorescence branch 0.3-1 times longer than its internode, with hairy branchlets throughout, 1-3 nodes, 3-10(30) flowers. Monochasia quite lax, the lateral with no stipule, with axis (0)0.3-1 of pedicel length, 3-5 flowers. Terminal monochasia with stipule $1-2$ of pedicel length, clear axis (1-2 of pedicel length), 4-6 flowers. Flowers of large size, hypanthia shortly obconical, with fruit shortly campanulate, without neck, glabrous or rarely with solitary hairs, (1.25)1.50-2.00 mm lg., w/1 ratio 72-92(100) \%; pedicels (1.5)2-5 hypanthia $\lg$., glabrous. Sepals narrowly triangular ovate, $1.50-1.90 \mathrm{~mm} \lg$., $95-120 \%$ of hypanthium $1 \mathrm{~g}$. , w/1 ratio $45-60 \%$, glabrous or rarely with solitary hairs. Epicalyx segments lanceolate, (1.50)1.75-2.50 mm lg., 100-122(167) \% of hypanthium lg., 100-143\% of sepal lg., width 47-65(89) \% of sepal width, w/1 ratio $20-27(43) \%$, glabrous or rarely with solitary hairs.

Distribution and habitat. Grows in grassplots in the Western Transcaucasus.

7. WTC: 7a. Tuap.-Adl., 7b. Abkh.

Affinity. The differences with $A$. muldaschevii see above; those with $A$. ptyschensis are hairy throughout stems, long axis of monochasium, and 
longer pedicels. There are not many species of $A$. ser. Calycinae with such long leaf lobes: $A$. transcaucasica Rothm., A. elevitensis Kalheber, A. kackarensis Kalheber - they differ by having glabrous lower leaf surfaces. A. procerrima S. E. Fröhner is distinguished by less dissected leaf blades (central zone from $75 \%$ of 1. 1.), shorter leaf lobes, $19-22 \%$ of 1. 1. for upper and medium leaves. A. tiryalensis Paw1. differs by having fewer teeth number of leaf lobes (to 7 at each side), orbicular leaves mostly without sinus, \pm hairy hypanthia.

Etymology. The species is named due to clear similarity in appearance to $A$. transcaucasica Rothm.

\section{$5,8)$}

Alchemilla ptyschensis Czkalov, sp. nov. (Figs.

(A. ser. Calycinae (Buser) Rothm., A. aggr. transcaucasica Rothm.).

Type: "[Georgia] Ermani, NE rocky slope of the Fidar-khokh volcano, 2500 m. 1938. V. Ya. Darbin" (LE-01072786!, specimen marked by asterisk).

Paratypes: "[Russia] Reg. auton. Karatshai, prope pag. Dombai, in faucib. fl. Ptysh ad cataractam I, in schistosis. 1937. S. Juzepczuk 935" (LE01072810!); "Kuban prov., alder forests along the Makhar river, near the veterinary post, 4500'. 1909. N. A., E. A. Busch 972" (LE-01072787!); "[Georgia] terrain Ermani, the left bank of the Ermanidon river, 1938, I. I. Abramov (LE-01072788!); "Ermani, the right slope of the Middle-Ermanian gorge, subalpine meadow. 1938. V. Ya. Darbin" (LE-01072789!).

Description. Plant of small or rarely medium size, up to $10-15(35) \mathrm{cm}$. Rhizome quite thick, up to $1.1 \mathrm{~cm}$. Stems 1(2), erect, rather robust, 1.5-2(3) times higher than radical leaves, up to $35 \mathrm{~cm}$, only at the lowermost internode sparsely hairy with appressed hairs.

Lower and medium radical leaves reniform to orbicular reniform with distinct sinus, with angle of sector $40-54^{\circ}$, glabrous in most, hairy only along the upper $1 / 3-1 / 2$ of main veins, sometimes sparsely at basal lobes beneath, along the margins; 5-7-lobed, with lobes $12-28 \%$, central zone $65-86 \%$ of 1.1 . Lobes plain or shortly trapezoid, obtuse, with incisions among lobes $7-14.5 \%$ of $1.1 ., 50-75 \%$ of lobe length, with 5-6 teeth at both sides of lobe, acutish, almost equally-sided, triangular mammillate, triangular falcate, straight, equally sized; length of standard tooth $7-11 \%$ of $1.1 ., 39-59 \%$ of lobe length, with apical tooth 55-68(86) \% of standard tooth length, much smaller than the neighboring ones, thus, lobes at the tops recessed. Leaves with (50)70-100 teeth in total. Petioles sparsely pubescent with appressed or subappressed hairs.

Upper radical leaves up to $25 \mathrm{~cm}$, leaf blade length 2-3(5) cm, orbicular with narrow sinus or less often overlapped basal lobes, plain, angle of sector from $40^{\circ}$, with the same indumentum; 7-9-lobed, lobes to $32 \%$, central zone from $58 \%$ of 1.1 ; with lobes trapezoid or arcuate, with incisions between lobes from $7 \%$ of 1.1 ., from $27 \%$ of lobe length, with distance between bases of incisions 108-131\% of lobe width, width $200-220 \%$ of lobe length; with $6-7(8)$ teeth at each side of lobe, acute, almost equally-sided, triangular or triangular falcate, straight, oblique, unequally sized, the lowermost teeth up to 2.5 times less than the standard tooth; length of standard tooth from $6 \%$ of $1.1 ., 22-35 \%$ of lobe length, with apical tooth $56-68 \%$ of standard tooth length. Leaves with $100-130$ teeth in total. Petioles sparsely pubescent with appressed or subappressed hairs. Stipules of radical leaves brown and purplish.

Stem leaves 3-4(5) per stem, assembled mostly in the upper half, beside the lowermost inflorescence branch reniform, subcordate or cuneate, with short petioles $1 / 5-1 / 3$, central zone $67-80(87) \%$ of 1. 1., 5-lobed, lobes (20)23-26\% of 1. 1., with 3-4(5) teeth at each side, plain to arcuate, with 46-70 teeth in total. Inflorescence rather narrow, with 3(4) inflorescence branches, assembled in the upper $2 / 5-2 / 3$ of stem. The lowermost inflorescence branch $0.5-$ 1.5 times longer than its internode, with glabrous branchlets, 3-5 nodes, 15-20(35) flowers. Monochasia quite lax, the lateral with stipule $1-2$ of pedicel length, clear axis (0.5-1.5 of pedicel length), 4-6 flowers. Terminal monochasia with stipule 1-3 of pedicel length, clear axis, 1-2 of pedicel length, 5-7 flowers. Flowers of large size, hypanthia shortly obconical, with fruit ovoid or spherical, with neck, glabrous or with a few hairs, (1.25)1.38-1.88 mm lg., w/1 ratio 57-74(96) \%; pedicels 1-2 hypanthia lg., glabrous. Sepals elongate triangular, 1.62-1.95 $\mathrm{mm} \lg$., 87-120(135) \% of hypanthium lg., w/l ratio 46-62 \%, glabrous. Epicalyx segments lanceolate, (1.50)1.75-2.00 mm lg., (80)93-140\% of hypanthium lg., 90-118\% of sepal lg., width 50-70(77) \% of sepal width, w/1 ratio $27-47 \%$, glabrous or rarely with solitary hairs.

Distribution and habitat. Grows in river floodplains, alder forests, subalpine meadows, on rocky slopes in the Western Ciscaucasus and Central Transcaucasus.

3. WC: 3c. Urup.-Teb.; 8. CTC: 8a. Kart.-S. Oss. 


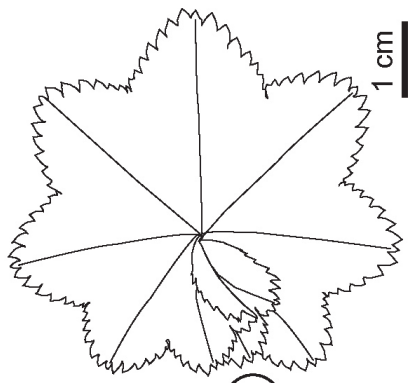

(A)

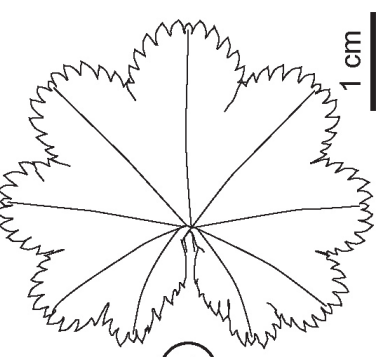

(B)

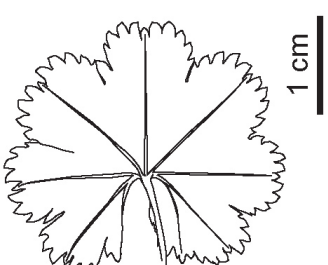

(C)
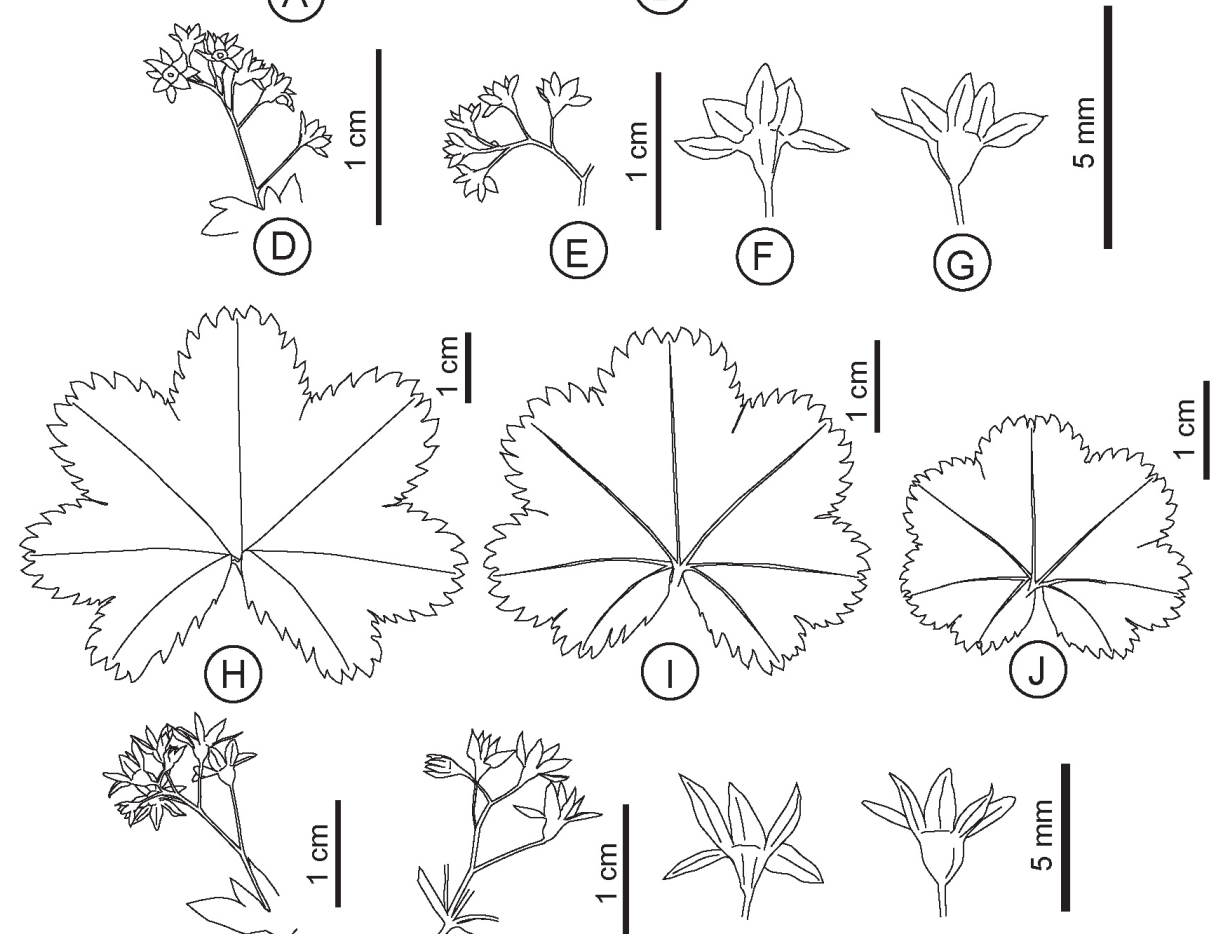

(K)

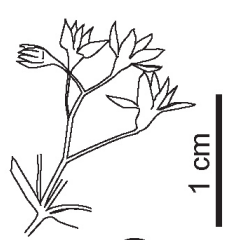

(L)

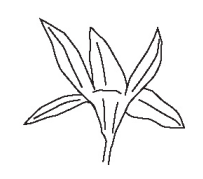

(M)

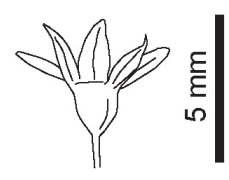

(N)
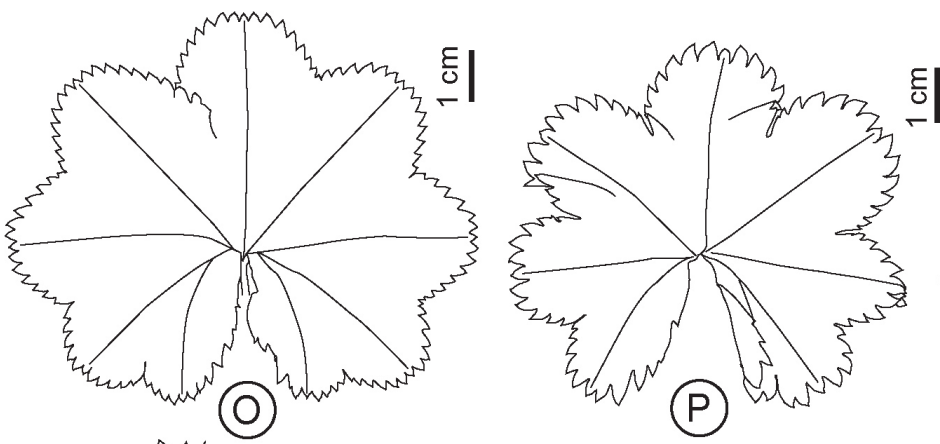

히
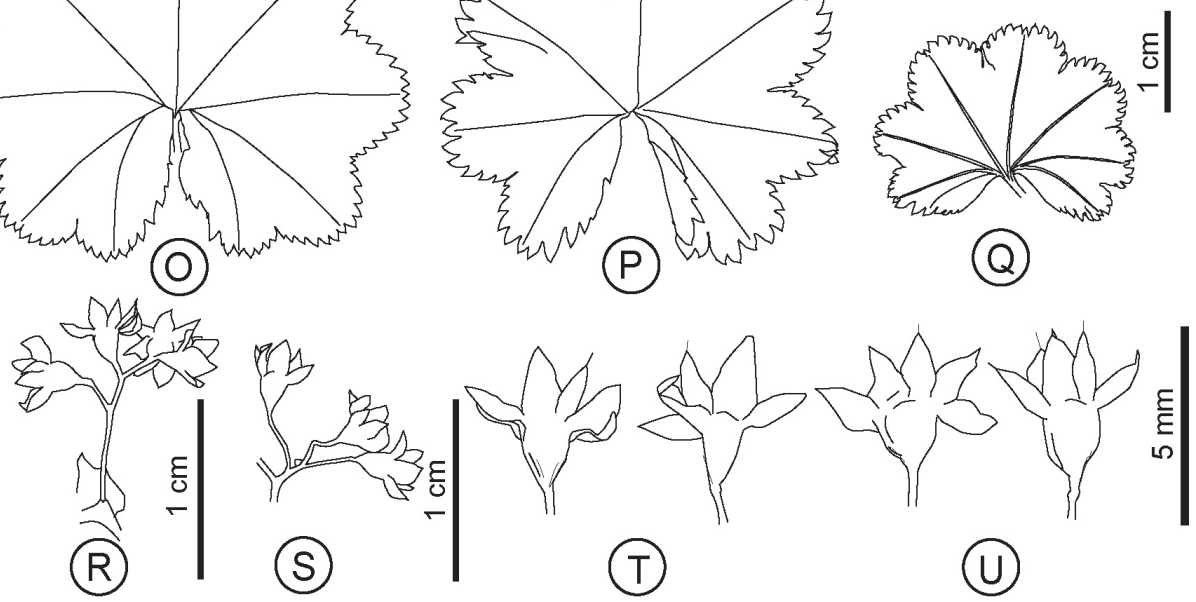

Fig. 5. Morphological features of Alchemilla species. A. muldaschevii: A - leaf blade of upper radical leaf; B - leaf blade of medium radical leaf; $\mathrm{C}$ - leaf blade of lower radical leaf; D - terminal monochasium; $\mathrm{E}$ - lateral monochasium; F - blooming flower; $\mathrm{G}$ - flower with mature fruit. A. pseudotranscaucasica: $\mathrm{H}$ - leaf blade of upper radical leaf; I - leaf blade of medium radical leaf; J - leaf blade of lower radical leaf; $\mathrm{K}$ - terminal monochasium; L - lateral monochasium; $\mathrm{M}$ - blooming flower; $\mathrm{N}$ - flower with mature fruit. A. ptyschensis: $\mathrm{O}$ - leaf blade of upper radical leaf; P - leaf blade of medium radical leaf; Q - leaf blade of lower radical leaf; R - terminal monochasium; $\mathrm{S}$ - lateral monochasium; $\mathrm{T}$ - blooming flowers; $\mathrm{U}$ - flowers with mature fruit. 


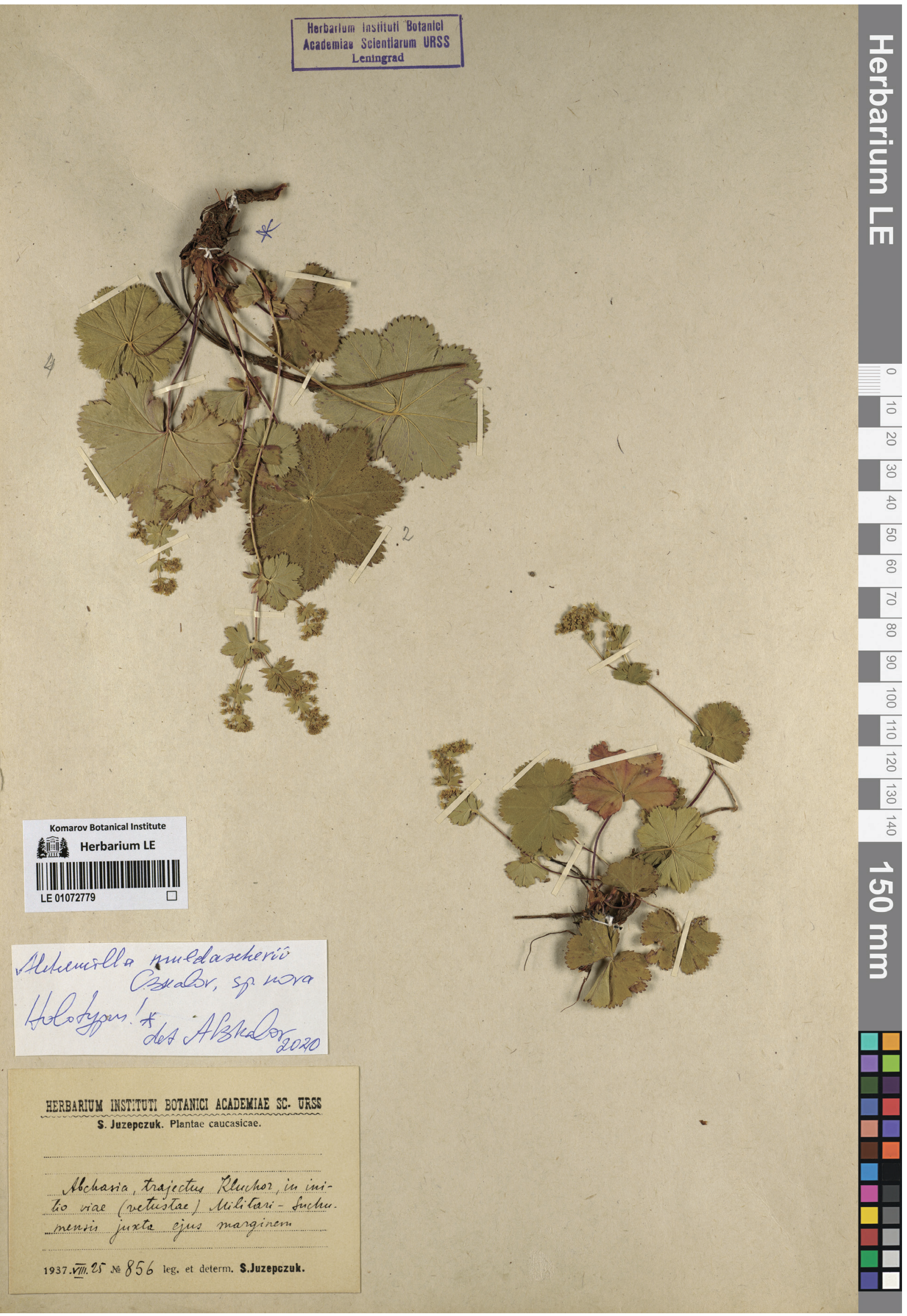

Fig. 6. Holotype specimen of Alchemilla muldaschevii. 


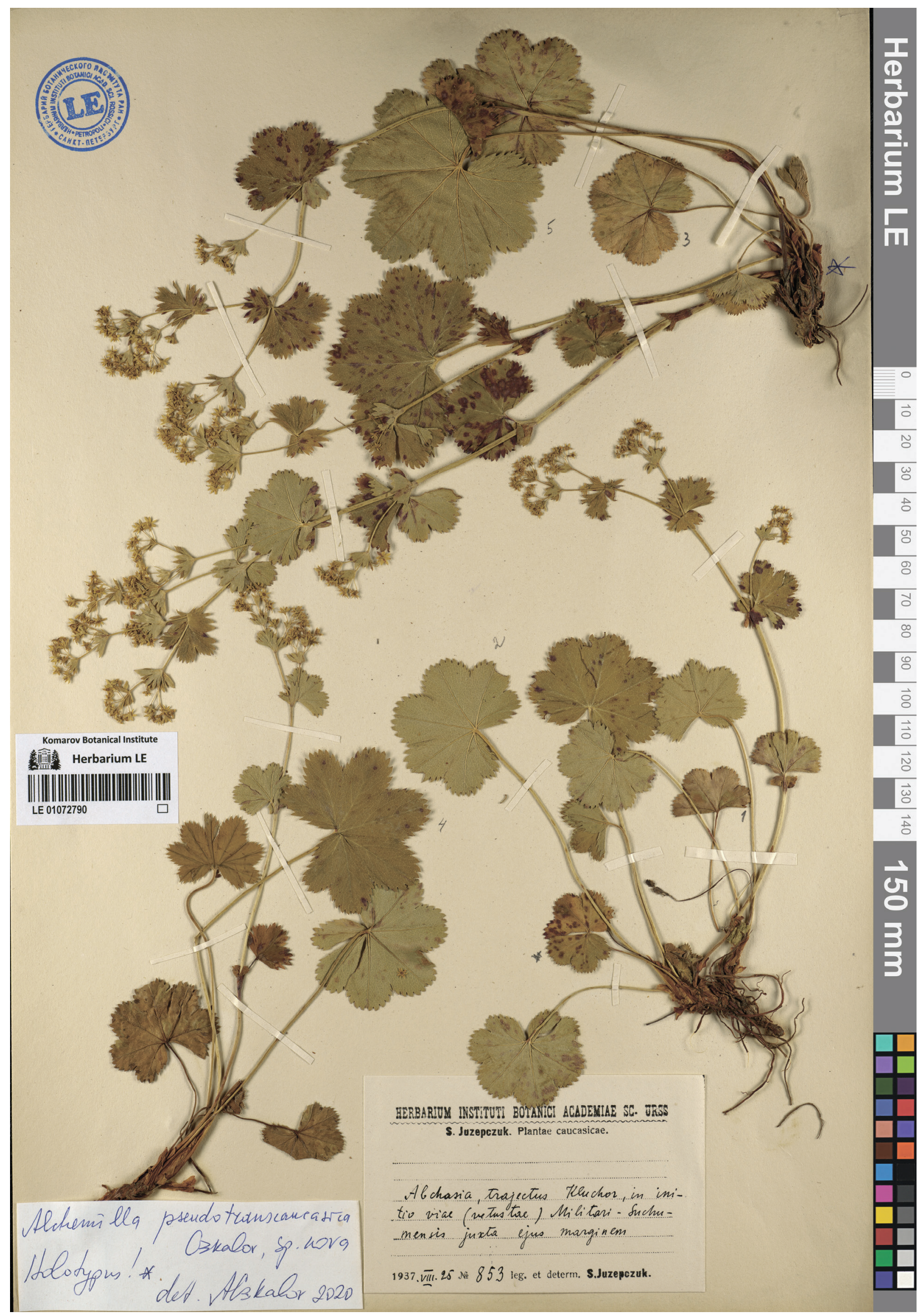

Fig. 7. Holotype specimen of Alchemilla pseudotranscaucasica. 


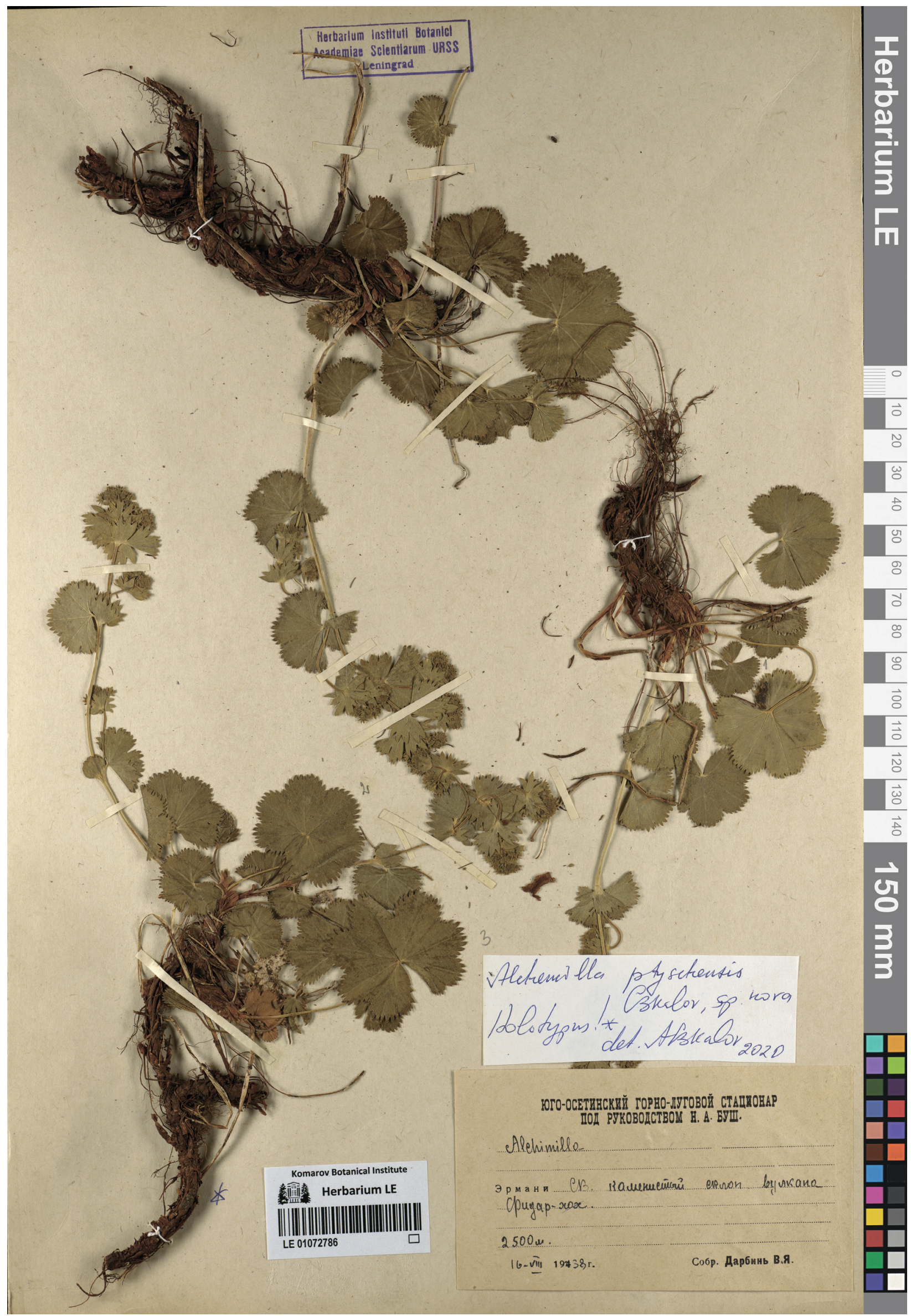

Fig. 8. Holotype specimen of Alchemilla ptyschensis. 
Affinity. Differences with A. muldaschevii and A. pseudotranscaucasica see above. A. retinervis Buser and A. dura Buser differ from this species by stems more highly pubescent, up to the half; also, the first one differs by entirely hairy main veins, and the second - by shorter leaf lobes (1/6-1/4 of leaf length). A. procerrima S. E. Fröhner is distinguished by stems higher pubescent (including the upper half), hairy radical leaves beneath and main veins throughout. A. debilis Juz. is similar by formal features but differs by having shorter leaf lobes $(1 / 5-1 / 4$ of 1 . 1.) with shorter incisions between them (0.5-1 of standard tooth length).

Etymology. The species is named after the river ("Ptysh") in basin of which it was collected.

Differentiating characters of described Alchemilla species

Table

\begin{tabular}{|c|c|c|c|c|c|c|}
\hline \multirow[t]{2}{*}{ Traits } & A. aggr. ellenbergiana & $A$. aggr. dura & \multicolumn{3}{|c|}{ A. aggr. transcaucasica } & A. aggr. abchasica \\
\hline & 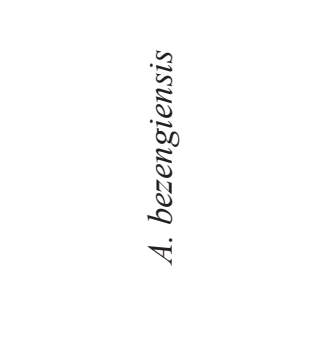 & 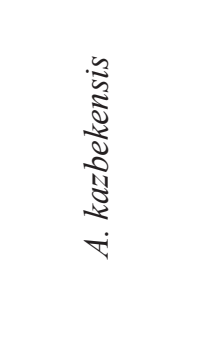 & 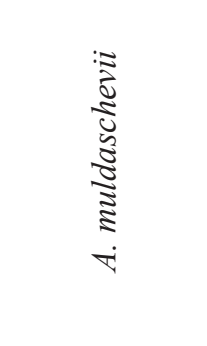 & 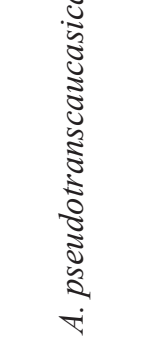 & 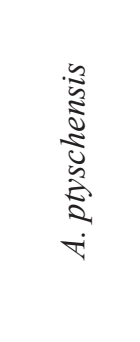 & 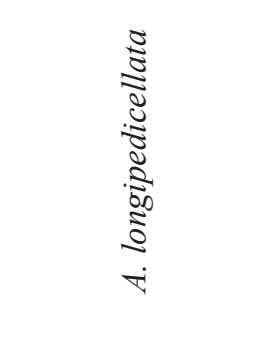 \\
\hline TTNL & $60-100$ & $90-125$ & $100-120(135)$ & $85-110$ & $100-130$ & $100-150$ \\
\hline TNLL & $4-5$ & $5-7(8)$ & $6-7$ & $7-9$ & $6-7(8)$ & $6-8(9)$ \\
\hline $\mathrm{CZ}$ & $67-74$ & $67-75$ & $59-77$ & $60-73$ & $58-86$ & $68-84$ \\
\hline ATL & $50-69$ & $67-100$ & $43-74$ & $43-53$ & $55-86$ & $32-50$ \\
\hline ID & $12-17$ & $6-12.5$ & $8-14$ & $5-13$ & $7-14.5$ & $6-14.5$ \\
\hline LLF & arc / semic & arc / semic & $\begin{array}{l}\operatorname{tr} / \text { tr-semic } \\
\quad / \operatorname{arc}\end{array}$ & $\begin{array}{l}\text { trap / } \\
\text { semiov }\end{array}$ & trap / arc & tr-semiov / arc \\
\hline SIS & 1 & $2 / 3$ & 0 & 1 & $1 / 4$ & $1 / 4$ \\
\hline SID & App & E & App & App & App & App \\
\hline PI & D & $\mathrm{D}$ & G & $\mathrm{S}$ & $\mathrm{S}$ & D \\
\hline PeL & $1.5-3(4)$ & $1.5-3(5)$ & $1.5-3(4)$ & $(1.5) 2-5$ & $1-2$ & $3-6(8)$ \\
\hline MAL & 0 & 1 & $1-2$ & $1-2$ & $1-2$ & $1-2$ \\
\hline $\mathrm{HI}$ & $\mathrm{D}$ & $\mathrm{G}$ & Gs & Gs & Gs & G \\
\hline $\mathrm{Ne}$ & No & Yes & No & No & Yes & No \\
\hline
\end{tabular}

Note. TTNL - total teeth number of the inner radical leaves; TNLL - teeth number on one side of the radical leaf lobe; $\mathrm{CZ}$ - central zone, \%; ATL - apical tooth to standard tooth length ratio, \%; ID - incision (between leaf lobes) to leaf length ratio, \%; SIH - stem indumentum spreading: from totally glabrous (0) to $1 / 4 \ldots 1 / 2 \ldots 2 / 3$ of the stem height hairy, and hairy throughout (1); LLF - leaf lobe form in the inner radical leaves: arc - arcuate, semic - semicircular, semiov - semiovate, tr-semic - semicircular somewhat triangular, tr-semiov - semiovate somewhat triangular, tr triangular, trap - trapezoid; SID - stem indumentum direction: App - appressed, E - erectopatent; PI - indumentum in petioles of the outer radical leaves: $\mathrm{D}$ - dense, $\mathrm{G}$ - glabrous, $\mathrm{S}$ - sparse; PeL - pedicel length: pedicel to hypanthia length ratio; MAL - axis length of the terminal monochasia: monochasia axis to pedicel length ratio; HI - hypanthia indumentum: D - dense, G - glabrous, Gs - glabrous with solitary hairs; Ne - presence of narrowing (a neck) under sepals in the upper part of hypanthium.

Bold frame - a unique feature among these species; grayish field - a specific value among the one-aggregate species.

\section{Acknowledgements}

I am grateful for the invaluable help with the search and digitization of authentic materials of many colleagues: J. Müller ("Herbarium Haussknecht", Friedrich Schiller University, Jena, Germany), A. Fleischmann, H.-J. Esser ("Botanische Staatssammlung München", Germany), R. Vogt ("Botanischer Garten und Botanisches Museum",
Berlin-Dahlem, Germany), M. A. Piirainen (Finnish Museum of Natural History, University of Helsinki, Finland), H. Smith (Royal Botanic Gardens Kew, London, UK), M. Graniszewska (University of Warsaw, Poland), W. Till, M. Hofbauer, D. Reich (University of Vienna, Austria), L. Cecchi, Ch. Nepi ("Museo di Storia Naturale, Università degli Studi di Firenze", Italy), C. Sarthou ("Muséum national 
d'Histoire naturelle", Paris, France), L. Gautier, L. Shvanova (V. L. Komarov Botanical Institute of Loze ("Conservatoire et jardin botaniques" (CJB), Russian Academy of Sciences, St. Petersburg) for Genève, Switzerland), M. Mosulishvili (Georgian their help and assistance during this study. This National Museum, Tbilisi, Georgia), Ü. Reier, K. work was carried out with the support of the RusOrav (University of Tartu, Estonia). I thank D. G. sian Foundation for Basic Research grant No 20-04Melnikov, I. V. Tatanov, A. V. Leostrin, and V. V. 00183.

\section{REFERENCES / ЛИTЕРАTУРA}

Buser R. 1893. Notes sur les plantes distribuées, et diagnoses des espèces nouvelles ou peu connues. Bulletin de l'Herbier Boissier 1, app. 2: 18-35.

Buser R. 1896. Sur quelque Alchimilles du Caucase. Bulletin de l'Herbier Boissier 4: 756-761.

Buser R. 1906a. Alchimillae nonnulae Caucasicae et Ponticae. Moniteur du Jardin Botanique de Tiflis 4: 1-9.

Buser R. 1906b. Alchimillae nonnulae Caucasicae et Ponticae. Moniteur du Jardin Botanique de Tiflis 5: 1-16.

Catalogue des herbiers de Genève (CHG). [2021]. Conservatoire \& Jardin botaniques de la Ville de Genève. URL: http://www.ville-ge.ch/musinfo/bd/cjb/chg (Accessed 25 January 2021).

Caucasian flora conspectus. 2008. A. L. Takhtajan (Ed.-in-chief). Yu. L. Menitsky, T. N. Popova, G. L. Kudrjashova, I. V. Tatanov (eds). Vol. 3(1). St. Petersburg; Moscow: KMK Scientific Press Ltd. 469 pp. [In Russian] (Конспекm флоры Кавказа / отв. ред. А. Л. Тахтаджян / ред. Ю. Л. Меницкий, Т. Н. Попова, Г. Л. Кудряшова, И. В. Татанов. Т. 3 (1). СПб.; М.: Тов-во науч. изд. КМК, 2008. 469 с.).

Chkalov A. V. 2011. New species of the genus Alchemilla (Rosaceae) from the Middle Volga basin. Bot. Zhurn. 96(12): 1633-1643 [In Russian and Latin] (Чкалов A. B. Новые виды рода Alchemilla (Rosaceae) из Среднего Поволжья // Бот. журн., 2011. Т. 96, № 12. С. 1633-1643).

Chkalov A. V. 2015. Alchemilla schmakovii sp. nov. from eastern Europe. Nordic Journal of Botany 33(5): 518521. DOI: $10.1111 / \mathrm{njb} .00804$

Chkalov A. V.2020. New delimitation of two series within Alchemilla subsection Calycanthum and new subdivision within Alchemilla series Calycinae (Rosaceae). Novitates Systematicae Plantarum Vascularium 51: 26-38. DOI: $10.31111 /$ novitates $/ 2020.51 .26$

Curators Herbarium B (2000+). Digital specimen images at the Herbarium Berolinense. Botanic Garden and Botanical Museum Berlin. URL: http://ww2.bgbm.org/herbarium/ (Accessed 25 January 2021).

FinBIF. [2021]. Finnish Biodiversity Information Facility. Finnish Museum of Natural History Luomus. URL: https://laji.fi/ (Accessed 25 January 2021).

Fröhner S. E. 1969. Alchemilla L. In: Flora Iranica. Bd. 66. K. H. Rechinger (Ed.). Graz: Akademische Druckund Verlagsanstalt. Pp. 124-147, 205.

Hayirlioğlu-Ayaz S. 2000. Alchemilla L. In: Flora of Turkey and the East Aegean Islands. Vol. 11. A. Güner, N. Özhatay, T. Ekim, K. H. C. Başer (eds). Edinburgh: Edinburgh Univ. Press. Pp. 103-114.

Hayirlioğlu-Ayaz S., Beyazoğlu O. 1997. A new species of Alchemilla (Rosaceae) from Turkey. Annales Botanici Fennici 34: 109-113.

Hayirlioğlu-Ayaz S., Kalheber H. 2002. Six new Alchemilla species from northeastern Anatolia. Sendtnera 8: $59-75$.

Herbarium Catalogue (S). [2021]. Naturhistoriska riksmuseet. URL: http:/herbarium.nrm.se/search/specimens/ (Accessed 25 January 2021).

JSTOR. [2021]. Global Plants on JSTOR. ITHAKA. URL: https://plants.jstor.org/collection/TYPSPE (Accessed 25 January 2021).

Juzepczuk S. V. 1933. Beschreibung neuer Arten der Gattung Alchimilla L. Acta Instituti Botanici AS URSS. Series 1 1: 117-131. [In Russian and Latin] (Юзепчук C. B. Новые виды рода Alchimilla L. // Труды Ботанического института АН СССР. Серия 1, 1933. Вып. 1. С. 117-131).

Juzepczuk S. V. 1934a. Alchimilla L. In: Grossheim A. A. Flora Kavkaza [Flora of Caucasus]. Vol. 5. Baku: Bakpolygraph. Pp. 320-330. [In Russian] (Юзепчук C. B. Alchimilla L. // Гроссгейм А. А. Флора Кавказа. Т. 5. Баку: Бакполиграф, 1934. С. 320-330).

Juzepczuk S. V. 1934b. Alchimillae nonnullae minus cognitae vel novae in Laboratorio Sectionis Systematicae educatae. In: Delectus seminum, quae Hortus botanicus Academiae Scientiarum USSR Leninopoli pro mutua commutatione offert in 1934. Leningrad: Editio Academiae Scientiarum USSR. Pp. 5-6.

Juzepczuk S. V. 1938. Genus Alchimilla L. in Tauria. Notulae systematicae ex Herbario Instituti Botanici nomine V. L. Komarovi Academiae Scientiarum URSS 8, 1-2: 3-28. [In Russian and Latin] (Юзепчук C. В. Род Alchimilla L. в Крыму // Ботанические материалы гербария Ботанического института АН CCCP, 1938. T. 8, вып. 1-2. C. $3-28)$. 
Juzepczuk S. V. 1941. Alchimilla. In: Flora SSSR [Flora of the USSR]. V. L. Komarov (Ed.). Vol. 10. Moscow, Leningrad: Academy of Sciences of USSR Publishing. Pp. 289-410. [In Russian] (Юзепчук С. В. Манжетка - Alchimilla L. // Флора СССР. Гл. ред. В. Л. Комаров. Т. 10. М.; Л.: Изд-во АН СССР, 1941. С. 289-410).

Juzepczuk S. V. 1957. №№ 4061-4080. In: Schedae ad herbarium Florae URSS ab Instituto Botanico Academiae Scientiarum URSS editum. B. K. Schischkin (Ed.). Vol. 14. Moscow, Leningrad: Publisher of AS URSS. Pp. 40-58. [In Russian and Latin] (Юзепчук C. В. №№ 4061-4080 // Список растений гербария флоры СССР, издаваемого Ботаническим институтом им. В. Л. Комарова АН СССР / под ред. Б. К. Шишкина. Т. 14. М.; Л.: Изд-во АН CCCP, 1957. C. 40-58).

Juzepczuk S. V. 1967. №№ 4702-4744. In: Schedae ad herbarium Florae URSS ab Instituto Botanico Academiae Scientiarum URSS editum. S. K. Czerepanov (Ed.). Vol. 17. Leningrad: Nauka, Leningrad Branch. Pp. 8-26. [In Russian and Latin] (Юзепчук C. В. №№ 4702-4744 // Список растений гербария флоры СССР, издаваемого Ботаническим институтом им. В. Л. Комарова АН СССР / под ред. С. К. Черепанова. Т. 17. Л.: Наука, Ленинградское отделение, 1967. С. 8-26).

Kalheber H. 1994. The genus Alchemilla L. (Rosaceae) in the Turkish vilayet Rize (northeastern Anatolia) with some remarks on the distribution of the genus in other parts of northern Anatolia. Sendtnera 2: 389-430.

Kew. [2021]. Royal Botanic Gardens Kew Herbarium Catalogue. Royal Botanic Gardens Kew. URL: http://apps. kew.org/herbcat/navigator.do (Accessed 25 January 2021).

MNHN. [2021]. Collection: Botany: Vascular plants. Muséum national d'Histoire naturelle [Paris]. URL: https:// science.mnhn.fr/institution/mnhn/collection/p/item/search (Accessed 25 January 2021).

Museo di Storia Naturale - Sezione Botanica "F. Parlatore” dell'Università di Firenze. [2021]. URL: http:// parlatore.msn.unifi.it/types/search.php (Accessed 25 January 2021).

Pawlowski B. 1972. De Alchemillis turcicis e subsectionibus Chirophyllum Rothm. et Calycanthum Rothm. sectionis Alchemilla. Fragmenta floristica et geobotanica 17, 1:3-44.

Pawlowski B., Walters S. M. 1972. Alchemilla L. In: Flora of Turkey and the East Aegean Islands. Vol. 4. P. H. Davis (Ed.). Edinburgh: University of Edinburgh Press. Pp. 80-105.

Ponert J. 1973. Neue Arten in der Gattung Alchemilla aus der Türkei und Kurdistan. Repertorium specierum novarum regni vegetabilis 83 : 501-505.

RBGE. [2021]. Royal Botanic Garden Edinburgh Herbarium Catalogue. Royal Botanic Garden Edinburgh. URL: https://data.rbge.org.uk/search/herbarium/ (Accessed 25 January 2021).

Rothmaler W. 1933. Systematische Vorarbeiten zu einer Monographie der Gattung Alchemilla. I. Repertorium specierum novarum regni vegetabilis 33: 854-862.

Rothmaler W. 1938. Systematik und Geographie der Subsektion Calycanthum der Gattung Alchemilla. Repertorium specierum novarum regni vegetabilis. Beihefte 100 (C): 59-93.

Rothmaler W. 1939. Systematische Vorarbeiten zu einer Monographie der Gattung Alchemilla (L.) Scop.: VIII. Neue Arten aus der Subsektion Heliodrosium Rothm. Repertorium specierum novarum regni vegetabilis 47: 454-464.

Seregin A. P. (Ed.). [2021]. Moscow Digital Herbarium: Electronic resource. Moscow State University, Moscow. Available at: https://plant.depo.msu.ru/ (Accessed 25 January 2021)) [In Russian] (Серегин А. П. (ред.) Цифровой гербарий МГУ: Электронный ресурс. М.: МГУ, 2021. URL: https://plant.depo.msu.ru/ (дата обращения: 25.01.2021).

Virtual Herbaria. [2021]. Department of Botany and Biodiversity Research, Universität Wien. URL: https://herbarium.univie.ac.at/database/search.php (Accessed 25 January 2021). 